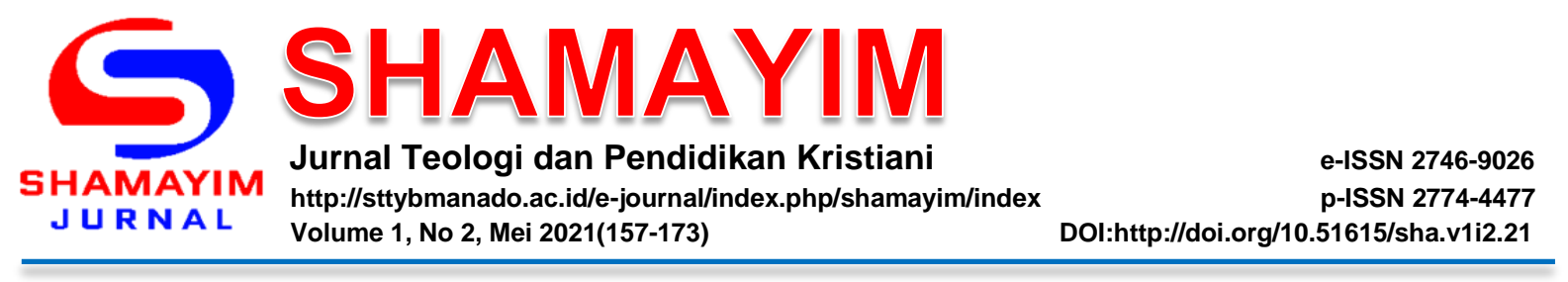

\title{
Kajian Teologis Peran Kepala Keluarga Kristen
}

Theological Study of the Role of the Head of the Christian Family

\author{
Yakub Hendrawan Perangin Angin ${ }^{1}$, Tri Astuti Yeniretnowati ${ }^{2}$ \\ ${ }^{1}$ Sekolah Tinggi Teologi Bethel The Way, ${ }^{2}$ Sekolah Tinggi Teologi Ekumene \\ lyakub.hendrawan@sttbetheltheway.ac.id, ${ }^{2}$ triastutiyeniretnowati2015@gmai.com
}

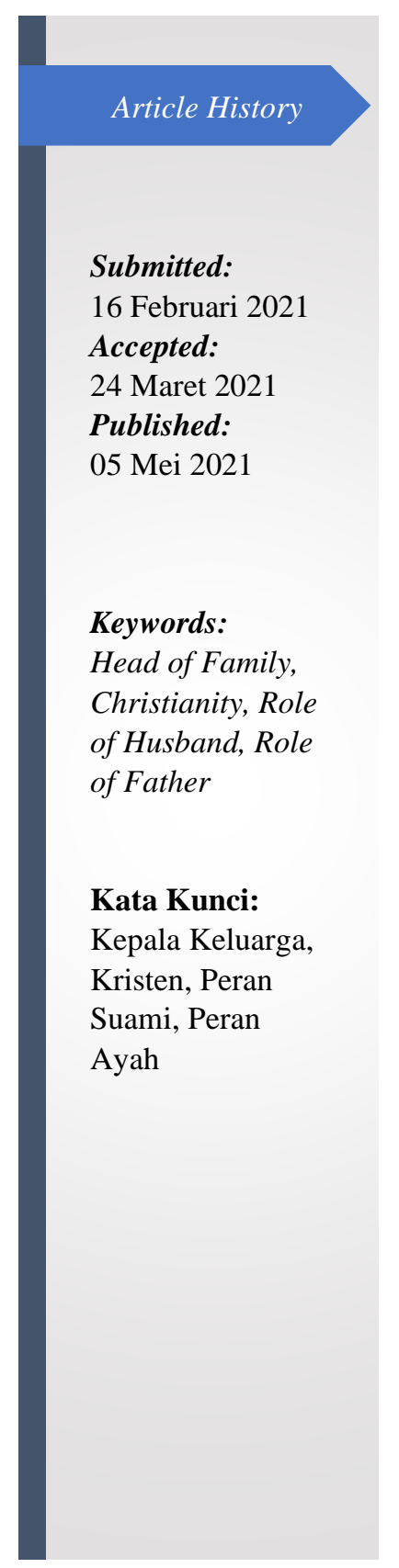

Abstract

Many husbands do not understand their responsibility to love their wives at all, and for centuries, many fathers have become fathers who do not play their roles properly so that they do not feel their positive contribution to society. The research method used in this research is the library research method. The purpose of this research is to review the important role of a man as head of a Christian family through theological studies. The results of this study conclude that the role as head of a Christian family is a mission of life responsibility and the correct response to the cultural mandate of God, and to be an effective head of a Christian family must have a vision of a great obsession that is planned, focused and has a goal according to biblical truth.

\begin{abstract}
Abstrak
Banyak para suami sama sekali tidak memahami tanggung jawabnya untuk mengasihi istrinya, dan juga sudah berabad-abad, banyak kaum bapa yang telah menjadi seorang ayah yang tidak memerankan perannya dengan baik sehingga tidak dirasakan kontribusinya yang positif bagi masyarakat. Metode penelitian yang digunakan dalam penelitian ini adalah metode penelitian kepustakaan. Adapun tujuan dari penelitian ini adalah untuk mengkaji kembali peran penting seorang pria sebagai kepala keluarga Kristen melalui kajian teologis. Hasil dari penelitian ini menyimpulkan bahwa peran sebagai kepala keluarga Kristen adalah sebuah misi pertanggungjawaban kehidupan dan respon yang benar atas mandat budaya dari Allah, dan untuk menjadi kepala keluarga Kristen yang efektif harus memiliki visi obsesi agung yang terencana, fokus dan mempunyai tujuan seturut kebenaran Alkitab.
\end{abstract}




\section{Pendahuluan}

Menurut undang-undang perkawinan nomor 1 tahun 1974 Pasal 1, pernikahan adalah ikatan lahir batin antara seorang pria dengan seorang wanita sebagai suami istri dengan tujuan membentuk keluarga yang bahagia dan kekal berdasarkan Ketuhanan yang Maha Esa. Berdasarkan definisi ini, dapat dilihat bahwa laki-laki akan memiliki peran baru sebagai seorang suami dan ayah, sementara wanita akan berperan sebagai seorang istri dan ibu, sehingga jelaslah bahwa ketika menikah, laki-laki dan wanita akan memiliki peran baru sebagai konsekuensi logis dari ikatan pernikahan. ${ }^{1}$

Beberapa abad terakhir, pria sudah menggunakan isu "kepemimpinan" sebagai sarana untuk menekan istri. Para pria sama sekali tidak memahami tanggung jawabnya untuk mengasihi selain mendengar bahwa ada perintah untuk tunduk bagi istri. Para pria merasa benar untuk "menjadi tuan" atas istrinya. Tak ayal lagi, istri membenci suaminya!. ${ }^{2}$ Selama berabad-abad, laki-laki telah meraih kebahagiaan tak terhingga dengan menjadi seorang ayah dan masyarakat pun tidak mendapatkan manfaatnya. Bahkan, kebanyakan masalah sosial yang dihadapi masyarakat berkaitan langsung dengan peran seorang ayah. ${ }^{3}$

Peran pria dalam keluarga sangat penting sampai-sampai Allah memakai peran itu untuk menyebut diri-Nya, Bapa. Kepala keluarga adalah pemimpin dan pemandu dalam keluarga dan cara dalam memimpin punya dampak panjang. Banyak keluarga hancur karena orangtuanya tidak peduli, banyak anak muda tidak punya arah, mencari jawaban yang harusnya diberikan oleh ayahnya lewat Firman dan perbuatan. ${ }^{4}$ Inti permasalahan adalah keluarga makin memburuk, bukan membaik dan ini sebagian besar disebabkan oleh para ayah. Kebanyakan ayah ingin melalukan sesuatu dengan benar, namun yang mereka tahu hanyalah menjadi "ayah yang menekankan penampilan". ${ }^{5}$ Peran ayah yang menekankan hati merupakan inti rencana Allah. ${ }^{6}$ Keluarga tidak hanya menjadi tempat pelarian dan persembunyian dari dunia. Terima kasih kepada Allah karena ada kekuatan di dalam rumah tangga. Allah menempatkan keluarga di dalam masyarakat untuk menjadi lampu penerangan penebusan dan keselamatan di dunia. ${ }^{7}$ Serta memperlengkapi kehidupan keluarga dalam kerohanian yang semakin berkenan dihadapan Tuhan dan menjadi berkat bagi sesama. ${ }^{8}$

Berkaitan dengan topik Peran Kepala Keluarga Kristen juga pernah diteliti oleh Gule dengan penelitian Peranan Kepala Keluarga Sebagai Imam di Tengah-tengah Keluarga Dimasa Pandemi Covid-19. ${ }^{9}$ Kesimpulan dari penelitian tersebut adalah bahwa Fungsi dan

\footnotetext{
${ }^{1}$ Dyah Purbasari Kusumaning Putri and Sri Lestari, "Pembagian Peran Dalam Rumah Tangga Pada Pasangan Suami Istri Jawa,” Jurnal Penelitian Humaniora 16, no. 1 (2016): 72-85.

${ }^{2}$ Don and Sally Meredith, Keduanya... Menjadi Satu, 1st ed. (Batam: Gospel Press, 2006), 161.

${ }^{3}$ Gregory W. Slayton, Be A Better Dad Today 10 Panduan Menjadi Ayah Hebat, 1st ed. (Jakarta: Persekutuan Gereja-Gereja Tionghoa Indonesia, 2015), 12.

${ }^{4}$ Voddie Baucham JR., Family Shepherds Gembala-Gembala Keluarga, 1st ed. (Bandung: Pionir Jaya, 2012), 8 .

${ }^{5}$ Patrick M. Morley, The Man In The Mirror, 1st ed. (Yogyakarta: Katalis, 2020), 13.

${ }^{6}$ Patrick Morley and David Delk, The Dad in the Mirror, 1st ed. (Yogyakarta: Andi Offset, 2004), 13

${ }^{7}$ Billy Joe Daugherty, Pernikahan Yang Kokoh, 4th ed. (Jakarta: Metanoia, 2006).

${ }^{8}$ Yonatan Alex Arifianto, "Pentingnya Pendidikan Kristen Dalam Membangun Kerohanian Keluarga Di Masa Pandemi Covid-19," REGULA FIDEI: Jurnal Pendidikan Agama Kristen 5, no. 2 (2020): 94-106.

${ }^{9}$ Yosefo Gule, "Peranan Kepala Keluarga Sebagai Imam Di Tengah-Tengah Keluarga Dimasa Pandemi Covid-19," Voice of Wesley: Jurnal Ilmiah Musik dan Agama 4, no. 1 (2020): 54-66.
} 
peranan utama kepala keluarga sebagai imam ialah menjalankan kebaktian atau ibadah keluarga baik pada hari minggu maupun pada hari-hari biasa; mengajarkan Firman Tuhan kepada keluarga; kepala keluarga mampu menuntun dan memimpin keluarganya untuk rajin membaca Firman Tuhan; mampu menuntun dan memimpin keluarganya untuk rajin dan tekun berdoa setiap hari; mampu menuntun dan memimpin keluarganya untuk setia mempersembahkan persepuluhan setiap bulan; setia memberikan persembahan ibadah keluarga setiap minggunya; mampu menjadi penasehat dan teladan yang baik bagi keluarga secara khusus di masa pandemi Covid-19. Di sisi lain seorang kepala keluarga bertanggung jawab menjaga kerohanian keluarganya di hadapan Allah yang memberikan keluarga dan yang memberkati-Nya. Tafonao melakukan penelitian serupa dalam artikel berjudul Peran Pendidikan Agama Kristen Dalam Keluarga Terhadap Perilaku Anak ${ }^{10}$, dengan kesimpulan bahwa peran orang tua termasuk kepala keluarga tentunya adalah memberi contoh pendidikan keluarga kepada anak mengenai nilai-nilai yang mempunyai dasar agama yang baik dan kuat sebagai solusi terhadap pergaulan bebas di kalangan pelajar yang sangat dikhawatirkan orang tua saat ini. Keluarga harus berfungsi sebagai wadah dalam membentuk karakter anak-anak dalam menghadapi berbagai masalah yang ada di zaman modern ini. Sementara penelitian lainnya yang menyinggung juga peran ayah sebagai imam dilakukan oleh Evimalinda, Prasetyo, dan Sihombing dalam artikel yang berjudul Urgensi Pemuridan Keluarga Sebagai Gereja Mini Dalam Akselerasi Amanat Agung di Tengah Pandemi Covid19. ${ }^{11}$ Salah satu kesimpulannya menyatakan, bahwa setiap ayah sebagai imam dapat membimbing spritualitas seluruh anggota keluarga dan anggota keluarga kepada orang lain di lingkungannya, sehingga setiap keluarga Kristen menemukan jati diri apa yang menjadi tugas dan tanggung jawab sebagai murid Tuhan Yesus dan apa yang bisa dilakukan dengan kehidupan yang dijalani sesuai dengan kapasitas melalui cara, dan strategi sendiri dengan memahami aspek-aspek iman dan panggilan sebagai murid Tuhan Yesus. Memuridkan orang lain memiliki arti tidak lain menjadikan mereka yang dimuridkan menjadi seperti orang percaya yang sedang mengikut Yesus. Berdasarkan ketiga penelitian tersebut masih ada hal-hal yang belum diteliti yaitu tentang peran kepala keluarga yang juga adalah memiliki peran sebagai seorang suami dan bagaimana konsep kepala keluarga dalam Alkitab baik Perjanjian Lama maupun Perjanjian Baru. Oleh sebab itu penelitian ini akan meneliti dan membahas tentang topik tersebut.

\section{Metode Penelitian}

Metode penelitian yang digunakan adalah metode penelitian dengan menggunakan kepustakaan. Sumber-sumber utama dari buku teks dan jurnal penelitian sebelumnya yang relevan dengan judul penelitian ini dikumpulkan. Selanjutnya analisis dilakukan dengan tinjauan pustaka yang sudah dipilih, yaitu dengan cara menganalisis tentang peran kepala keluarga sebagai sebuah kerangka konsep. Sumber utama dari analisis adalah beberapa

10 Talizaro Tafonao, "Peran Pendidikan Agama Kristen Dalam Keluarga Terhadap Perilaku Anak," Edudikara: Jurnal Pendidikan dan Pembelajaran 3, no. 2 (2018).

${ }^{11}$ Rita Evimalinda, Eko Prasetyo, and P A K Sihombing3 Prodi, "Urgensi Pemuridan Keluarga Sebagai Gereja Mini Dalam Akselerasi Amanat Agung Di Tengah Pandemi Covid-19” (n.d.). 
sumber relevan, hasil penelitian dan buku yang sesuai dengan pembahasan. Semua sumber selanjutnya dianalisis dengan cara mencermati hubungan dan kecocokan dengan judul penelitian. Hasil analisis selanjutnya diuraikan secara deskriptif dan sistematis. ${ }^{12}$ Penelitian ini diharapkan memberikan bingkai teologis bagaimana peran kepala keluarga kristiani.

\section{Hasil dan Pembahasan}

\section{Pendapat Para Ahli Keluarga Tentang Peran Kepala Keluarga}

Menurut Dobson bahwa yang terkandung dalam "pria berkeluarga yang baik" di dunia masa kini, ada empat peranan yang dimainkan oleh pria di dalam keluarga, yaitu: Pertama, melayani sebagai pencari nafkah keluarga. Kedua, melayani sebagai seorang pemimpin keluarga. Ketiga, melayani sebagai pelindung. Keempat, memberi pengarahan rohani dalam keluarga. ${ }^{13}$ Sedangkan Parsons menyatakan bahwa kunci untuk menyentuh hati seorang anak ialah dengan menyatakan kepadanya bahwa kepala keluarga mencintainya, apa pun keadaannya. Tidak ada kekuatan yang lebih besar di muka bumi ini untuk membangun hubungan yang kuat kecuali dengan cinta yang tak bersyarat. Anak-anak dari ayah yang demikian mengetahui bahwa apakah mereka menang dalam perlombaan, atau menduduki tempat terakhir dalam perlombaan, tidak peduli, apakah mereka gemuk atau kurus, berhasil atau gagal, mereka tetap dicintai. Komitmen ayah kepada mereka janganlah didasarkan atas keberhasilan mereka, melainkan atas dasar hubungan pribadi dengan anak. Keyakinan inilah yang akan mengikat seorang anak dengan ayahnya. ${ }^{14}$ Menurut Chapman bahwa salah satu tanda dari keluarga fungsional adalah bahwa suami seorang pemimpin pengasih. Kedua, kata penting. Kepemimpinan tanpa kasih dapat menjadi penindasan. Kasih tanpa kepemimpinan dapat menjadi kelemahan. Kepemimpinan pria dinyatakan dalam dua hubungan dalam keluarga: sebagai suami dan ayah. Suami yang bertanggung jawab, dapat diandalkan, memimpin tetapi tidak dominan, yang komitmennya besar terhadap keluarganya. ${ }^{15}$

Selanjutnya Thomas, mengatakan bahwa memberikan teladan moral sama seperti membuat jalan di tengah hutan. Kekacauan melingkupi anak-anak, mereka butuh orangtua yang berjalan di depan untuk menunjukkan jalan. Mereka harus melihat bagaimana orangtua yang sudah dibuat kewalahan oleh hidup, memperoleh rasa aman dan pengharapan di dalam Allah yang lebih besar dari diri manusia. Mereka juga harus melihat bagaimana orangtua berusaha untuk hidup tidak egois, bahkan penuh pengorbanan jika perlu, untuk mencari dahulu Kerajaan Allah. Orangtua mencontohkan sikap takut akan Allah yang benar, menghormati Allah, menaati firman Tuhan, hidup di jalan yang Allah perintahkan, dan menanamkan rasa benci akan dosa. ${ }^{16}$ Paul dan Tsika, mengatakan bahwa pria harus menjadi

${ }^{12}$ Sonny Eli Zaluchu, "Struktur Artikel Untuk Jurnal Ilmiah Dan Teknik Penulisannya," in Strategi Menulis Jurnal Untuk Ilmu Teologi, ed. Sonny Eli Zaluchu, 1st ed. (Semarang: Golden Gate Publishing Semarang, 2020), 1-21.

${ }^{13}$ James Dobson, Mendidik Putra Anda, 2nd ed. (Jakarta: Immanuel, 2006), 92-93.

${ }^{14}$ Rob Parsons, 60 Menit Ayah - Satu Jam Untuk Mengubah Kehidupan Anak Anda, 2nd ed. (Jakarta: Immanuel, 2002), 68-73.

${ }^{15}$ Gary Chapman, Five Signs of a Functional Family, 1st ed. (Batam: Interaksara, 2000).

${ }^{16}$ Gary Thomas, Devotions for Sacred Parenting, 1st ed. (Yogyakarta: Yayasan Gloria - Katalis, 2013), 15. 
kepala keluarga, tetapi menjadi kepala yang mengendalikan seluruh keluarga bukanlah pola yang ada dalam pikiran Tuhan ketika Ia pertama kali mengadakan lembaga pernikahan. Contoh-nya selalu supaya suami mengasihi dan melayani istri sama seperti Yesus mengasihi dan melayani jemaat. Walaupun tidak ada keraguan bahwa Yesus adalah Kepala Gereja, Ia mendefinisikan hubungan itu dengan cara yang sangat berbeda ketika Ia memilih untuk memanggil murid-murid-Nya sahabat dan bukan hamba dalam Yohanes 15:15-16.

Inilah yang dimaksudkan dengan persahabatan perjanjian hubungan agape yang selalu mau memberkati orang lain. Ia memberitahukan murid-murid-Nya bahwa Ia tidak akan menyembunyikan apa pun dari mereka, tetapi terbuka dan jujur dalam kepemimpinan-Nya, bahwa pelayanan bersama adalah sebuah kemitraan, bukan kediktatoran. Saat berbicara tentang mereka yang mau menjadi pemimpin, Yesus berkata, "Jika seseorang ingin menjadi yang terdahulu, hendaklah ia menjadi yang terakhir dari semuanya dan pelayan dari semuanya" (Mrk.9:35). Inilah juga pola untuk menjadi pemimpin bagi keluarga. ${ }^{17}$

\section{Konsep Keluarga Kristiani Bahwa Keluarga Pusat Rencana Allah}

Keluarga menjadi pusat rencana Allah. Sejak awal, Allah merancang bahwa, melalui keluarga, pesan-Nya harus disampaikan kepada generasi-generasi berikutnya (Ul.6; Mzm.78). ${ }^{18}$ Menurut Efesus 5 dan 6 peran ayah adalah mengasihi istri dan memuridkan anak-anak. Tugas orangtua terhadap anak-anak adalah melatih anak-anak agar mereka memusatkan hidup pada Injil. ${ }^{19}$ Rumah dalam Mazmur 127:1, “...Jikalau bukan Tuhan yang membangun rumah, sia-sialah usaha orang yang membangunnya; jikalau bukan Tuhan yang mengawal kota, sia-sialah pengawal berjaga-jaga", dapat diartikan sebagai pernikahan atau keluarga. Dengan kata lain, maksud ayat ini adalah bahkan jika seorang penjaga terbangun dan melihat musuh datang serta tahu bagaimana melawannya, tanpa Tuhan maka kota itu tetap akan dikuasai musuh. Demikian juga dengan keluarga. Jika Tuhan tidak membangun dan bekerja dalam keluarga dan kehidupan orang percaya, semua usaha yang orang pecaya jalankan tidak akan berhasil. Orang yang percaya kepada Kristus harus memiliki kekuatan Allah pada saat ini juga dalam rumah tangga, pernikahan dan keluarga. ${ }^{20}$

\section{Konsep Peran Kepala Keluarga Sebagai Suami}

\section{Dasar Alkitab Peran Para Suami}

Dalam Efesus 5:22-23, Paulus menantang para suami untuk memimpin istri dan mengasihinya sebagaimana Kristus mengasihi jemaat. Ini sama sekali bukan tugas ringan. Para suami harus menjadi pemimpin sekaligus kekasih. Ini bukan boleh salah satu/atau, tetapi keduanya/dan. Kedua aspek itu memimpin dan mengasihi harus hadir bersamaan, boleh dikatakan bahwa seorang suami seperti inilah yang dapat meninggalkan warisan termahal yang pernah diberikan kepada anak-anaknya. Kasih suami kepada istri harus menjadi nyata dahulu baru dapat nyata di antara ayah dan anak. ${ }^{21}$ Ketika Paulus

\footnotetext{
${ }^{17}$ Paul and Billie Kaye Tsika, Get Married, Stay Married, 1st ed. (Jakarta: Immanuel, 2012), 158-159.

${ }^{18}$ Morley and Delk, The Dad in the Mirror.

19 JR., Family Shepherds Gembala-Gembala Keluarga.

${ }^{20}$ Daugherty, Pernikahan Yang Kokoh.

${ }^{21}$ Steven J. Lawson, Warisan Abadi, 2nd ed. (Jakarta: Metanoia, 2005).
} 
menggambarkan hubungan suami dan istri dalam Efesus 5:22-23, "Hai istri, tunduklah kepada suamimu seperti kepada Tuhan, karena suami adalah kepala istri sama seperti Kristus adalah kepala jemaat. Dialah yang menyelamatkan tubuh". Paulus mengawalinya dengan menetapkan bahwa suami adalah kepala istri. Jelaslah bahwa pria adalah kepala istrinya, seperti Kristus adalah kepala jemaat-Nya. ${ }^{22}$

Apakah arti menjadi seorang suami? Focus on the Family memberikan beberapa kualitas untuk membantu para suami agar memperoleh definisi yang benar, yaitu: Pertama, Cinta ditunjukkan lewat pengurbanan dan komitmen. Kedua, Kepemimpinan dan keberanian, dimana pemimpin harus terlebih dahulu belajar bagaimana melayani, kemudian baru bisa memimpin melalui teladannya. Dan keberanian untuk mengakui kesalahannya dan berpartisipasi dalam proses pertumbuhan kedewasaannya sendiri. Ketiga, Prioritaskan istri, yaitu harus belajar mengenali kebutuhan istrinya, meletakkan di atas kebutuhannya sendiri, serta memberi tanggapan, baik fisik maupun emosional. Keempat, Komunikasi dan ungkapan terimakasih, dimana harus terus menerus belajar mengenal istrinya, berkomunikasi, baik verbal maupun non-verbal. Kelima, Kesatuan. Diantara begitu banyaknya langkah yang harus diambil pria dalam pernikahannya untuk menjadi seorang suami yang berarti, yang terpenting adalah komitmen pada diri sendiri untuk memenuhi panggilan Tuhan, yaitu memenuhi kebutuhan istrinya. ${ }^{23}$

\section{Arti Suami Menjadi Kepala}

Pada masa kini, para suami salah memahami perannya sebagai pemimpin rohani di dalam keluarga dan juga adanya penundukan diri istri terhadap suami. Untuk itu diperlukan pemikiran yang jernih dan alkitabiah. Empat kata kunci kebenaran tentang kepala di dalam rumah tangga, yaitu: Pertama, Kesetaraan. Kedua, Otoritas. Ketiga, Tanggung jawab. Keempat, Keintiman. ${ }^{24}$ Seorang suami hanya akan memahami tantangan Kristus jika suami memahami bagaimana hidup dalam kuasa Roh Kudus dan mengenali pikiran Kristus. Tanpa sudut pandang ini, seorang pria tidak akan pernah menjalankan perannya dengan baik. Dengan sudut pandang itu, seorang suami dapat memahami apa artinya merendahkan diri kepada istrinya, dan apa artinya mengasihi istrinya. ${ }^{25}$ Suami juga harus mengerti peranan yang diberikan oleh Allah kepadanya sebagai kepala rumah tangga, mengasihi istri, dan melindungi istri. Suami harus mempertanggung jawabkan peranannya kepada Allah yang menganugerahkan kepadanya. Suami haruslah seorang yang takut akan Tuhan untuk dapat menjalankan peranannya dengan baik tanpa merusak rancangan Allah dalam hubungannya dengan istri. ${ }^{26}$

\footnotetext{
22 Ibid.

${ }^{23}$ Focus On The Family, Menjadi Suami Yang Andal, 1st ed. (Yogyakarta: Andi Offset, 2009), 2-5.

${ }^{24}$ Lawson, Warisan Abadi.

${ }^{25}$ Don and Meredith, Keduanya... Menjadi Satu.

${ }^{26}$ Yosua Sibarani and Yonatan Alex Arifianto, "Studi Analisis Makna Kata 'Berahi' Dan 'Berkuasa' Dalam Kejadian 3:16 Dan Implikasinya Bagi Rumah Tangga Kristen Masa Kini,” Sola Scriptura: Jurnal Teologi 1, no. 2 (2020): 118-134.
} 


\section{Arti Suami Mengasihi Istri}

Efesus 5:25, "Hai suami, kasihilah istrimu sebagaimana Kristus telah mengasihi jemaat dan telah menyerahkan diri-Nya baginya". Setiap pria, sebagai seorang pemimpin, harus mengasihi istrinya dengan cara yang istimewa. Memimpin tanpa mengasihi sama juga dengan sikap diktator. Ada beberapa bentuk kasih yang menuntut perhatian, sehingga kasih suami harus berbentuk: Pertama, Kasih tanpa syarat. Kedua, Kasih yang memberi. Ketiga, Kasih yang tidak bercela. Keempat, Kasih yang pengertian. Dan Kelima, Kasih tanpa akhir. ${ }^{27}$ Perjanjian Baru menjelaskan bagaimana peran-peran ini diterapkan dalam keseharian. Suami harus merawat dan mengasuh. Beginilah Rasul Paulus menggambarkan suami yang mengasihi istrinya: "Demikian juga suami harus mengasihi istrinya sama seperti tubuhnya sendiri: Siapa yang mengasihi istrinya mengasihi dirinya sendiri. Sebab tidak pernah orang membenci tubuhnya sendiri, tetapi mengasuhnya dan merawatinya, sama seperti Kristus terhadap jemaat, karena kita adalah anggota tubuh-Nya." (Ef.5:28-30). Suami harus mengasihi istri seperti mereka mengasihi tubuhnya sendiri.

Pada umumnya pria secara naluri menyadari nilai dari tubuhnya; mereka tidak perlu secara sadar memikirkan bagaimana menyayangi tubuhnya. Seandainya ada seseorang atau sesuatu, yang melukai atau mengancam tubuhnya, pria menyikapinya dengan langkah yang memperbaiki. Tuhan mengajar para pria tentang betapa penting istrinya. Para suami harus mengasuh dan merawat istri, kedua kata ini adalah cara-cara jitu untuk menggambarkan kasih yang Tuhan sedang bicarakan. Mengasuh, yang hanya digunakan sebanyak dua kali dalam Perjanjian Baru, secara harfiah berarti "memelihara kesehatan pada suhu yang tepat". Kata ini digunakan untuk menggambarkan induk burung yang mengayomi anak-anaknya di bawah sayapnya pada suhu tubuh yang tepat. Suami harus begitu terlibat dalam memedulikan istrinya sehingga mereka setiap saat tahu apa yang perlu dilakukan untuk memenuhi kebutuhan istri. ${ }^{28}$ Kata bahasa Yunani untuk bagaimana kaum pria harus mengasihi istri sama dengan kata yang digunakan dalam Alkitab untuk menggambarkan kasih Allah kepada dunia. "Karena Allah begitu mengasihi dunia ini, sehingga Ia telah mengaruniakan Anak-Nya yang tunggal (Yoh.3:16). Kasih seperti itu juga yang harus dinyatakan kepada Allah. "Kasihilah Tuhan, Allahmu, dengan segenap hatimu dan dengan segenap jiwamu dan dengan segenap akal budimu" (Mat.22:37). Alkitab mengarahkan untuk mengasihi dengan kasih berdasarkan kehendak, bukan kasih yang emosional. Kasih yang alkitabiah itu kasih agape, yang berarti mengasihi dalam pengertian moral; kasih ini merupakan tindakan yang digerakkan oleh kehendak sebagai suatu prinsip, tugas, dan kesusilaan. $^{29}$

\footnotetext{
${ }^{27}$ Lawson, Warisan Abadi.

${ }^{28}$ Don and Meredith, Keduanya... Menjadi Satu.

${ }^{29}$ Morley, The Man In The Mirror.
} 


\section{Konsep Peran Kepala Keluarga Sebagai Ayah}

\section{Dasar Alkitab Peran Ayah}

Berdasarkan Efesus 6:4, "Dan, kamu, bapa-bapa, janganlah bangkitkan amarah di dalam hati anak-anakmu, tetapi didiklah mereka di dalam ajaran dan nasihat Tuhan", dan ayat yang serupa Kolose 3:21, Allah secara khusus menunjukan perintah ini kepada para ayah. Mengapa Allah melakukan hal ini? Karena kebapaan menurut Alkitab mewajibkan kepala keluarga, sebagai pria, menjadi pemimpin rohani dalam rumah tangga masingmasing. Kepala keluarga melakukannya bukan secara sukarela, bukan juga karena apa yang menjadi pilihannya. Sebaliknya, secara sadar dan menerima apa yang telah ditunjuk oleh Tuhan sendiri untuk menjadi pemimpin bagi keluarga. Setiap ayah sebagai kepaka keluarga bertanggungjawab untuk mempersiapkan, meninggalkan, dan menjaga warisan rohani bagi anak-anaknya. Para ayah sudah dipilih oleh Allah untuk meninggalkan nilai-nilai rohani yang mendasar yaitu kebajikan-kebajikan yang ilahi. ${ }^{30}$ Menurut Kitab Suci, seorang ayah mendorong dan menghibur anak-anaknya, mendesak mereka untuk "hidup sesuai dengan kehendak Allah" (1Tes.2:11-12). Seorang ayah bertanggung jawab memberikan pengajaran (Ams.1:8-9) dan pendisiplinan (Ibr.12:10) kepada anak-anaknya. Seorang ayah diharapkan memberikan "pemberian yang baik" kepada anak-anaknya (Mat.7:9-11). Yang lebih berat, seorang ayah tidak boleh menjadikan anak-anaknya "frustasi" ketika melakukan semuanya itu. Sebagai gantinya dan yang terpenting adalah seorang ayah harus "mendidik mereka di dalam ajaran dan nasihat Tuhan" (Ef.6:4). ${ }^{31}$

Allah menetapkan peran seorang ayah dengan tujuan kekal, untuk menyatakan dan mewakili diri-Nya. Bukan karena ayah duniawi itu seperti diri-Nya sehingga Dia memutuskan untuk memanggil diri-Nya Bapa. Sebaliknya, dalam kekekalan Dia hadir sebagai Allah Bapa di surga dan sengaja menciptakan peran ayah di bumi untuk mengungkapkan siapa diri-Nya dan menunjukkan kepada kepala keluarga natur hubunganNya dengan Anak-Nya. Semua peran ayah berasal dari-Nya (Ef.3:14-15). Setiap ayah dipanggil untuk menjadi representasi Allah yang hadir tiap hari secara fisik bagi anakanaknya dan untuk memperkenalkan diri-Nya kepada generasi berikutnya. Ketika seorang anak melihat ayahnya di dunia, ia seharusnya dapat melihat kualitas-kualitas Allah berikut ini: seorang penyedia yang penuh kasih, seorang pelindung yang kuat, seorang pemimpin yang penuh kebenaran, seorang pemegang otoritas yang terhormat, dan seorang sahabat yang dekat. Hal ini mempengaruhi cara anak berpikir. "Jika ayahku di dunia mengasihi dan memperhatikan aku, maka Bapa Surgawi mengasihi dan memperhatikan aku. Jika ayahku sungguh-sungguh dalam ucapannya, maka Tuhan sungguh-sungguh dalam ucapan-Nya. Jika ayahku bersedia mati bagiku, maka Tuhan bersedia mati bagiku." 32 .

Ukuran kebapaan yang asli dan efektif adalah Allah sendiri yang merupakan sumber dari segala sesuatu yang baik (Yak.1:17). Dia adalah "Bapa, yang dari pada-Nya berasal segala sesuatu “(1Kor.8:6b). Dia menghembuskan napas kehidupan kepada manusia

\footnotetext{
${ }^{30}$ Lawson, Warisan Abadi.

${ }^{31}$ James Dobson and Shirley Dobson, Night Light For Parents, 1st ed. (Tangerang: Gospel Press, 2007),

${ }^{32}$ Stephen and Alex Kendrick, The Resolution For Men, 1st ed. (Bandung: Pionir Jaya, 2014), 29.
} 62. 
pertama, dan Adam menjadi "anak Allah" (Luk.3:37). Dia adalah Bapa yang lembut, yang mengundang setiap anak-Nya untuk menyapa-Nya sebagai "Abba," kata Aramis yang sama dengan "Papa," atau "Dada" (Rm.8:15, Gal.4:6). Dia adalah Bapa yang mendengarkan, yang meminta orang percaya menghampiri-Nya dengan penuh keberanian sebagai "Bapa kami yang di sorga" (Mat.6:9). Dia adalah Bapa yang mengasihi (Mat.3:17). Dia adalah Bapa yang memberi pemberian yang baik kepada anak-anak-Nya (Mat.7:11). Dia adalah Bapa dari semua (Ef.4:6), definisi kebapaan yang tepat, sumber segala sesuatu yang baik, bermoral, dan layak untuk diteladani. ${ }^{33}$

\section{Potret Suram Gagalnya Peran Ayah}

Alkitab menunjukkan bahwa kemerosotan rohani ini berawal ketika sebuah generasi ayah gagal "mewariskan yang baik-baik" kepada generasi berikutnya. Kitab Hakim-hakim 2:10 menyatakan, "Setelah seluruh angkatan itu dikumpulkan kepada nenek moyangnya, bangkitlah sesudah mereka itu angkatan yang lain, yang tidak mengenal Tuhan ataupun perbuatan yang dilakukan-Nya bagi orang Israel." Dan apa akibatnya bagi mereka? Ayatayat berikutnya menunjukkan bahwa generasi baru ini "melakukan apa yang jahat", "meninggalkan Tuhan", "mengikuti dan menyembah allah-allah lain", dan "menyakiti hati Tuhan”. Dan apa yang Tuhan lakukan terhadap mereka? Hakim-hakim 2:14-15 mengatakan bahwa Tuhan "menyerahkan mereka ke dalam tangan perampok dan menjual mereka kepada musuh di sekeliling mereka, sehingga mereka tidak sanggup lagi menghadapi musuh mereka". Tangan Tuhan melawan mereka, dan mereka sangat menderita. Tidak seorang pun di antara para ayah, bahkan setelah merenungkan sekejap saja, akan "melimpahkan" tragedi semacam ini secara sadar kepada anak-anaknya. Walaupun begitu, banyak para ayah menerima warisan semacam itu dari ayah generasi sebelumnya, dan sekarang banyak ayah generasi saat ini sedang mengulangi siklus pewarisan itu. Keluarga akan kehilangan seluruh generasi penerus jika Tuhan tidak turut serta untuk membuat hati para ayah dalam era ini untuk berbalik kepada anak-anaknya. ${ }^{34}$

Kisah imam Eli juga menunjukkan bahwa peran seorang ayah sangat besar pengaruhnya, wahai para ayah, jangan pernah meremehkan pengaruh ayah yang luar biasa terhadap anak-anak. Pengaruh ayah dapat menghasilkan perbedaan antara bencana dengan kehidupan yang sukses serta berkenan di mata Allah. Imam Eli mempunyai dua orang putra, yaitu Hofni dan Pinehas. Jelas dikisahkan bahwa Eli gagal mendisiplinkan kedua putranya tersebut ketika masih kecil; mereka tidak menghormati Eli. Mereka memberontak terhadap Eli dan terhadap firman Allah, mengambil hewan korban jemaat untuk mereka makan sendiri dan mengancam siapa pun yang melawan mereka (1Sam.2:12-17). Ketika Eli mendengar tentang perbuatan kedua putranya, ia berbicara kepada mereka, tetapi mereka mengabaikan peringatan Eli (ayat 23-25). Perbuatan mereka menyinggung Allah, pada akhirnya mendatangkan penghakiman (3:11-13) dan maut (4:17). ${ }^{35}$

\footnotetext{
${ }^{33}$ Josh McDowell, The Father Connection, 1st ed. (Jakarta: Metanoia, 2004), 23.

${ }^{34}$ Morley and Delk, The Dad in the Mirror.

${ }^{35}$ Dobson and Dobson, Night Light For Parents.
} 


\section{Tantangan dan Peluang Bagi Kepala Keluarga}

Pemikiran dan Tindakan Keliru Dari Ayah

Kendati sebagian besar ayah Kristen berkata bahwa kepedulian utama mereka adalah memastikan bahwa anak-anak mereka menjadi anak yang baik, banyak di antara mereka mengarahkan anak-anak laksana pilot otomatis. Para ayah cuma berharap dan berdoa bahwa dengan suatu cara bagaimanapun caranya, oleh kasih karunia Tuhan, anak-anak mereka akan hidup bagi Kristus, dan Kristus harus menjadi pusat kehidupan serta kerinduan yang dikerjakan untuk memuliakanNya terlebih sikap dan prilaku memprioritaskan hidup bagi Kristus sebagai fokus dalam keluarga. ${ }^{36}$

Para ayah menyayangi anak-anaknya, namun membiarkan anak-anak itu hidup sesuka hati. Para ayah yang lebih tekun sering beranggapan bahwa sudah selayaknya para ayah membuat anak-anaknya melakukan segala sesuatu dengan benar. Para ayah berusaha keras agar anak-anak melakukan segala sesuatu dengan benar. Para ayah berusaha keras agar anakanak memenuhi berbagai harapan orangtua. Namun, tidak fokus pada hati anak-anak sehingga begitu banyak anak "bermoral" bertumbuh dengan menolak Kristus. Mereka berkomentar, "Ayah hanya berfokus agar saya taat - tetapi ayah tidak pernah peduli. Tidak secara pribadi." 37

\section{Peran Ayah Yang Salah Yang Menekankan Penampilan}

Terlalu banyak ayah Kristen menyibukkan diri dengan penampilan anak-anak. Sepanjang anak-anak mereka tampil baik, tidak bermasalah di sekolah, bersih dan rapi, para ayah percaya bahwa segala sesuatunya baik-baik saja. Namun, Alkitab berkata, "Manusia melihat apa yang di depan mata, tetapi Tuhan melihat hati" (1Sam.16:7). Tatkala menjadi ayah yang menekankan penampilan, disiplin yang diterapkan memaksa anak-anak untuk berhenti melakukan sesuatu yang tidak orangtua inginkan. Orangtua menetapkan peraturan dan hukuman agar anak-anak mengikuti dan melakukan apa yang orangtua harapkan. Ayah yang menekankan penampilan berarti ayah yang berfokus untuk menyingkirkan perilaku yang tidak diinginkan dan menggantikannya dengan perilaku yang diterima. Mungkin, hasilnya akan dirasakan untuk sesaat, namun dampak buruknya akan berkepanjangan. ${ }^{38}$

\section{Melatih Melalui Keteladanan}

Jika tujuan dari tugas orangtua adalah untuk membesarkan anak-anak yang benar dan ilahi, maka cara mencapainya adalah melalui pelatihan. Orangtua harus melatih anak-anak dengan sengaja dan dengan tujuan, dan ini menuntut perencanaan. Untuk itu tugas orangtua harus direncanakan. Pelatihan tidak berjalan begitu saja. Anak-anak ilahi tidak muncul kebetulan, mereka adalah produk upaya berkomitmen dari orangtua ilahi. Untuk mendapatkan nasihat yang bijaksana dalam membesarkan anak-anak ilahi sebaiknya

${ }^{36}$ Sri Lina Betty Lamsihar Simorangkir and Yonatan Alex Arifianto, "Makna Hidup Adalah Kristus Berdasarkan Filipi 1: 21 Dan Implikasinya Bagi Orang Percaya," CARAKA: Jurnal Teologi Biblika dan Praktika 1, no. 2 (2020): 228-242.

${ }^{37}$ Morley and Delk, The Dad in the Mirror.

${ }^{38}$ Ibid. 
berpegang pada Firman Allah. ${ }^{39}$ Ayah adalah pelatih keluarga juga dinyatakan oleh Josh Weidmann dan Jim Weidmann. Pelatih adalah seseorang yang memimpin dan mengarahkan dengan cara berjalan berdampingan, bukan dengan menggendong seseorang. Ayah dapat mengajarkan tentang hidup kepada anak-anaknya, tetapi pelajaran yang sesungguhnya barulah dimulai ketika mereka harus menerapkan apa yang telah ayah ajarkan. ${ }^{40}$ Proses pelatihan ini meliputi pelatihan dalam keterampilan (seperti: membaca, menulis, naik sepeda), bagaimana berespons terhadap perasaan-perasaan (seperti: takut, marah, kecewa), dan juga meliputi pengembangan watak dengan tekanan pada nilai-nilai dasar seperti, kejujuran, kerja keras, dan keberanian. Orangtua melatih melalui teladan, karena anak-anak pertama-tama dan terutama belajar dari teladan orangtua. Mereka senantiasa mengamati tindakan-tindakan dan gaya hidup orangtua. ${ }^{41}$

\section{Menerapkan Disiplin}

Disiplin adalah pemuridan, mengajarkan Alkitab dan memberi teladan dalam berdoa, serta hal lainnya termasuk menegur perilaku yang tidak selaras dengan kehidupan keluarga dan Alkitab, juga adalah bagian dari disiplin. Melalui kehidupan bersama, para ayah mengkomunikasikan apa yang diharapkan satu sama lain dan melatih generasi baru dengan hati, intuisi, dan keterampilan yang mereka butuhkan bagi masa depan. ${ }^{42}$ Alat disiplin ilahi adalah kasih, bukan tongkat. Tongkat itu mengkomunikasikan kasih, itu adalah pelaksanaan kasih. Firman Tuhan berkata, "Siapa tidak menggunakan tongkat, benci kepada anaknya; tetapi siapa mengasihi anaknya, menghajar dia pada waktunya" (Ams.13:24). Disiplin desakan untuk memperbaiki adalah tindakan kasih yang dirancang untuk mengarahkan kembali pemikiran, sikap, dan tingkah laku anak ke jalur yang benar. Itu merupakan bagian yang sangat penting dari pelatihan seorang anak dalam jalan yang seharusnya ia tempuh supaya cara berpikir, bersikap, dan bertingkah laku akan menjadi gaya hidup. ${ }^{43}$ Disiplin sangat diperlukan dalam kehidupan anak-anak karena itu membantu mempersiapkan mereka untuk masa depan. Alkitab berkata, "Hajarlah anakmu selama ada harapan, tetapi jangan engkau menginginkan kematiannya" (Ams.19:18). Ayat ini memberitahukan kita paling sedikit dua hal. Pertama, disiplin dan harapan memang berhubungan, dan Kedua, kurangnya disiplin berhubungan dengan kematian. Ada sepuluh prinsip atau pedoman sederhana untuk menolong memastikan bahwa disiplin yang diterapkan memang sesuai, efektif, dan diterima oleh anak-anak, yaitu: Pertama, bersikap konsisten. Kedua, jangan mendisiplin dalam kemarahan. Ketiga, perlakukanlah anak-anak sama rata. Keempat, jangan pernah izinkan anak-anak meremehkan disiplin. Kelima, jangan izinkan anak-anak memberontak. Keenam, jangan izinkan anak-anak mengeluh tentang pendisiplinan mereka. Ketujuh, jangan izinkan anak-anak menjadi pahit hati. Kedelapan, jangan izinkan anak-anak menjadi malas.

\footnotetext{
${ }^{39}$ Myles Munroe and David Burrows, Kingdom Parenting, 1st ed. (Jakarta: Immanuel, 2009).

40 Josh Weidmann and Jim Weidmann, Ayah Aku Ingin Bicara, 1st ed. (Yogyakarta: Gloria Graffa, 2006), 130.

${ }^{41}$ Chapman, Five Signs of a Functional Family.

${ }^{42}$ Russell Moore, Keluarga Di Tengah Badai Dunia, 1st ed. (Jakarta: OMID Publishing House, 2020).

${ }^{43}$ Munroe and Burrows, Kingdom Parenting.
} 
Kesembilan, jangan pernah menyuruh atau menuntut anak-anak untuk melakukan apa pun yang para ayah sendiri tidak ingin lakukan. Dan Kesepuluh, jangan pernah mencemooh, merendahkan, atau memperlakukan anak-anak, terutama di depan umum. ${ }^{44}$

Bagi orang Kristen, Alkitab berulang kali mengingatkan tentang disiplin yang diterima dari Allah Bapa sebagai analogi untuk disiplin yang harus diberikan dan diterima, di dalam keluarga. Dalam Kitab Ibrani ada bagian yang mengatakan kepada gereja bahwa sama seperti bapa mereka di dunia mendisiplin mereka, Allah juga mendisiplin mereka. Penulis Kitab itu berkata, jika mereka tidak disiplin, mereka bukan anak tapi anak yang tidak sah (Ibr.12:5-11). Dengan demikian, penulis Ibrani sedang merujuk pada beberapa bagian Perjanjian Lama yang berbicara tentang Allah mendisiplin umat-Nya, Israel, "seperti bapa mendisiplin anaknya". ${ }^{45}$ Perjanjian Lama penuh dengan contoh jelas tentang peran keluarga dalam mendisiplinkan anak-anak. Bagi umat Tuhan di Perjanjian Lama, "doa pagi, dan malam, hari-hari raya, dan agama keluarga menjadi ciri utama di rumah. Sejumlah ayat di Perjanjian Lama menunjukkan peran seorang ayah untuk memuridkan anak-anaknya (contohnya, Ul.6:6-7; Mzm.78; Ams.4), dan di beberapa bagian lain dari Alkitab, pemuridan dikatakan tidak boleh dilewatkan. ${ }^{46}$

\section{Aplikasi Peran Kepala Keluarga Yang Baik dan Sehat}

\section{Kebutuhan Terpenting Keluarga}

Keluarga membutuhkan suatu "sistem" kebapaan yang dengan sempurnanya dirancang untuk melatih anak-anak mengasihi Tuhan dan sesama dengan segenap hati. ${ }^{47}$ Seorang ayah seharusnya tidak berfokus pada upaya untuk membuat anak-anaknya melakukan segala sesuatu dengan benar, namun lebih untuk membuat mereka mengasihi Tuhan dan sesama dengan segenap hati. Apabila anak-anak mengasihi Tuhan dengan segenap hati, jiwa, akal budi, dan kekuatan mereka, maka perilaku yang benar pun akan mengikuti. ${ }^{48}$ Hubungan ayah dengan anak-anak adalah jendela yang menolongnya untuk mengenal Allah dan juga diri sendiri serta harga dirinya. Anak-anak dapat menemukan nilai dan harga dirinya dalam suatu "cermin", yakni orang-orang yang terdekat dengannya. Bisa melalui cara memandang, mendengar, dan menyentuh; melalui apa yang para ayah katakan kepadanya atau tentang anak-anak di hadapan anggota keluarga yang lain; juga melalui banyaknya waktu yang diluangkan baginya. Kerap kali kesan pertama ini akan melekat dalam diri anak-anak di sepanjang usianya. ${ }^{49}$ Sebagai orangtua, alasan hidup yang terpenting adalah meneruskan tongkat estafetnya Injil dengan aman kepada anak-anak (Yoh.3:3), dan pada 3 Yohanes 1:4 dikatakan, "Bagiku tidak ada sukacita yang lebih besar daripada mendengar, bahwa anak-anakku hidup dalam kebenaran". ${ }^{50}$

\footnotetext{
44 Ibid.

${ }^{45}$ Moore, Keluarga Di Tengah Badai Dunia.

46 JR., Family Shepherds Gembala-Gembala Keluarga.

${ }^{47}$ Morley and Delk, The Dad in the Mirror.

${ }^{48}$ Ibid.

${ }^{49}$ H. Norman Wright and Gary J. Oliver, Raising Kids To Love Jesus, 3rd ed. (Yogyakarta: Gloria
} Graffa, 2013).

${ }^{50}$ Dobson and Dobson, Night Light For Parents. 


\section{Peran Ayah Yang Menekankan Hati}

Tripp menggunakan frasa "menggembalakan hati" untuk memberikan bentuk yang jelas terhadap proses membimbing anak, yang berarti membantu anak memahami diri, karya Allah, jalan-jalan Allah, bagaimana dosa bekerja dalam hati manusia, dan bagaimana Injil sampai kepada anak-anak pada tingkat paling mendasar dari kebutuhan manusia. Menggembalakan hati anak-anak juga mencakup membantu anak-anak mengerti berbagai motivasi, tujuan, keinginan, harapan dan hasrat. Hal ini memaparkan ciri sebenarnya dari realitas dan mendorong iman kepada Tuhan Yesus Kristus. ${ }^{51}$ Seorang ayah melihat apa yang dilakukan dan mengapa anak melakukannya. Hadiah dan hukuman dapat diterapkan, namun hanya jika difokuskan pada perubahan kesadaran yang utama di hati anak. Peran ayah yang menekankan hati berarti: Pertama, melihat suatu persoalan dari sudut pandang yang utuh. Kedua, mengejar sasaran yang benar. Ketiga, melatih anak untuk mengasihi Allah dan sesama. Keempat, mengusir kebodohan. ${ }^{52}$ Oliver juga menekankan pentingnya orangtua kristiani masa kini agar belajar untuk memantau hati dan membantu anak-anak mengenali diri sendiri dan mengenali hal-hal yang terpenting bagi mereka. Amsal 20:5 mengatakan, "Rancangan di dalam hati manusia itu seperti air yang dalam, tetapi orang yang pandai tahu menimbanya." 53 Alkitab mengajarkan bahwa hati adalah pusat yang mengendalikan hidup. Kehidupan seseorang adalah cerminan dari hatinya. Amsal 4:23 menyatakannya seperti ini: "Jagalah hatimu dengan segala kewaspadaan, karena dari situlah terpancar kehidupan.". Hati merupakan sebuah mata air dari mana segala macam persoalan kehidupan memancar ke luar. Perilaku seseorang adalah ekspresi yang meluap dari hati. Hati menentukan perilaku: Perkataan dan perbuatan seseorang menyatakan orientasi dari hatinya (Mrk.7:21). ${ }^{54}$

\section{Peran Ayah Menjadi Pengajar}

Tujuan akhir menjadi orangtua kristiani bukan sekadar mendidik agar anak mempunyai pengetahuan tentang Allah, melainkan agar anak mempunyai hubungan pribadi dengan Allah dan benar-benar percaya bahwa firman Allah relevan dalam setiap aspek hidup mereka. Menjadi orangtua kristiani berarti juga mengajarkan jalan Allah. Membantu mereka memahami sifat-sifat Allah. Membantu mereka agar peka terhadap kegelapan hati mereka sendiri dan sadar betapa berbahayanya berjalan sendiri dan mengandalkan diri sendiri. Mengajar mereka tentang kuasa salib dan kepastian janji-janji Allah. Allah memanggil para ayah untuk memimpin, mengarahkan, mengasihi, memperbaiki, dan mendisiplinkan anakanak. Allah dengan kuasa-Nya memberi para ayah wewenang terhadap anak. Tanggung jawab itu harus diterima dengan sukacita.

Dalam Kejadian 18:19, Allah berbicara tentang Abraham ketika berfirman, "Sebab Aku telah memilih dia, supaya diperintahkannya kepada anak-anaknya dan kepada keturunannya supaya tetap hidup menurut jalan yang ditunjukkan Tuhan, dengan melakukan kebenaran dan keadilan". Dalam Efesus 6:4, para ayah diperintahkan untuk mendidik anak-

\footnotetext{
${ }^{51}$ Tedd Tripp, Shepherding A Child's Heart, 1st ed. (Malang: Gandum Mas, 2002), 146.

${ }_{52}$ Morley and Delk, The Dad in the Mirror.

${ }^{53}$ Wright and Oliver, Raising Kids To Love Jesus.

54 Tripp, Shepherding A Child's Heart.
} 
anak "di dalam ajaran dan nasihat Tuhan". Anak-anak akan mengambil keputusan yang baik bila melihat teladan orangtua yang beriman, setia memberi petunjuk, dan tahu mengambil keputusan yang bijaksana bagi anak-anaknya. ${ }^{55}$ Hal yang sama akan pentingnya ayah melakukan apa yang diajarkan kepada anaknya sebagai salah upaya yang efektif dalam mendidik ditegaskan oleh Ingram, yang menyatakan bahwa untuk menjadi orangtua yang efektif menuntut orangtua untuk melakukan apa yang diajarkan. Anak-anak tidak membentuk hidup mereka dengan apa yang orangtua katakan. Mereka adalah pengamat sikap dan perilaku, dan orangtua adalah figur yang pertama dan penting bagi mereka. Perintah-perintah orangtua hanya bisa masuk bila anak-anak melihatnya didukung oleh karakter dan gaya hidup yang konsisten dengan kata-kata orangtua. Singkatnya, menjadi orangtua memerlukan banyak integritas. ${ }^{56}$ Serta melibatkan Allah dalam menjalankan fungsinya sebagai kepala keluarga merupakan faktor penting dalam perjalanan keluarga. ${ }^{57}$

\section{Mewariskan Hal Yang Abadi}

Anak-anak belajar dari apa yang mereka jalani dalam kehidupannya. Mereka menyerap pengetahuan tentang dunia melalui kejadian-kejadian yang mereka alami dan amati. Anak-anak lebih banyak belajar dari mengamati perilaku orang-orang dewasa daripada belajar dari perkataan atau nasihat. Mereka peka terhadap "kurikulum tersembunyi" di balik pengajaran yang disampaikan lewat metode dan struktur yang bisa memperkuat atau justru bertentangan dengan isi pelajaran tersebut. Jika kepala keluarga berbicara tentang kasih dan kepedulian, tetapi tidak ada kehangatan di rumah, maka anak justru akan lebih dipengaruhi oleh kenyataan di balik kata-kata tersebut. Keluarga terus memainkan peran kunci dalam membentuk kerohanian pada masa anak-anak yang panjang. Seiring dengan berlalunya waktu, susunan keluarga terus berubah sesuai dengan berbagai irama kehidupan. Namun, keluarga masih tetap menjadi pusat di mana hubungan-hubungan keakraban itu terbentuk dan membentuk ulang nilai-nilai, ide-ide dan pola-pola kehidupan. ${ }^{58}$ Orangtua mempersiapkan anak-anaknya dengan memberi mereka identitas yang positif, orangtua mengajar anak-anaknya dengan memberi teladan yang jelas. ${ }^{59}$ Orangtua harus jadi teladan dalam memberi contoh, jadilah model kesalehan. ${ }^{60}$

\section{Menolong Anak Agar Serupa Seperti Kristus}

Kunci untuk menolong anak yang dipercayakan agar menjadi serupa dengan Kristus ialah dengan memahami anak-anak dan memastikan bahwa mereka tahu orangtuanya

${ }^{55}$ Wright and Oliver, Raising Kids To Love Jesus. 2006), 13.

${ }^{56}$ Chip Ingram, Effective Parenting In A Defective World, 1st ed. (Tangerang: WorldTeach Indonesia,

57 Yonatan Alex Arifianto and Joseph Christ Santo, "Iman Kristen Dan Perundungan Di Era Disrupsi," Angelion: Jurnal Teologi dan Pendidikan Kristen 1, no. 2 (2020): 149-163.

${ }^{58}$ Marjorie L. Thompson, Keluarga Sebagai Pusat Pembentukan, 5th ed. (Jakarta: BPK Gunung Mulia, 2012), 13-15.

${ }^{59}$ Ed Young, The 10 Commandments Of Parenting, 1st ed. (Bandung: Lembaga Literatur Baptis, 2005), 62.

\footnotetext{
${ }^{60}$ Young, The 10 Commandments Of Parenting.
} 
memahami mereka. ${ }^{61}$ Amsal 22:6 "Didiklah orang muda menurut jalan yang patut baginya, maka pada masa tuanya pun ia tidak akan menyimpang daripada jalan itu." Bukankah kalimat ini membuktikan hal yang sama seperti yang diklaim berikut ini, "Jika Anda mengikuti formula yang tepat, maka anda akan menjadi orangtua yang berhasil"?. Petuah ini tak memberi janji bahwa Allah akan senantiasa dan dalam setiap kasus menyelamatkan anak-anak, tak peduli seberapa tekun orangtua mengarahkan anaknya kepada Allah. Barangkali orangtua telah mendisiplinkan anak-anak di jalan yang seharusnya anak-anak tempuh, tetapi anak-anak meninggalkan jalan tersebut. Jangan serta-merta berasumsi bahwa pembangkangan anak-anak itu sebagai akibat dari kesalahan orangtua. Namun, cobalah pahami apa yang diajarkan Alkitab, yakni ada tiga faktor yang menentukan bagaimana seorang anak itu jadinya: Pertama, Orangtua bertanggung jawab untuk secara rendah hati memuliakan Tuhan dan mematuhi dengan penuh keimanan Sabda Allah dalam mendisiplinkan anak-anak. Kedua, Anak-anak bertanggung jawab dengan kerendahan hati memuliakan orangtuanya dan Tuhan dengan mematuhi penuh keimanan. Ketiga, Allah adalah pengendali yang berkuasa penuh dalam kehidupan para orangtua dan anak-anak, mengarahkan anak-anak sesuai dengan tujuan-Nya yang baik.

\section{Kesimpulan}

Keluarga dibentuk Allah agar dapat menjadi wadah yang kuat dan tangguh dimana suami istri saling melengkapi, saling bersatu hati, seperasaan, sepemikiran dalam menciptakan suasana yang mengupayakan tercapainya visi keluarga yang dipimpin oleh kepala keluarga agar semua pribadi anggota keluarga dapat menjadi pribadi yang seperti Yesus yang berkenan bagi Allah. Kepala keluarga bertanggung jawab untuk membawa dan memastikan keluarganya mampu melalui semua rintangan dan pilihan-pilihan yang ditawarkan oleh dunia yang semakin cemar ini. Harus waspada karena dunia saat ini bukanlah tempat yang aman bagi anak-anak juga istri, karena banyak sekali nilai-nilai dan kegiatan-kegiatan yang dapat menggerus standar nilai moral dan iman kristiani. Betapa besar peranan kepala keluarga dalam menciptakan kesejahteraan melalui bimbingan dan pendidikan bagi seluruh anggota keluarganya secara bertanggung jawab, karena kehidupan keluarga Kristen adalah tentang pertanggungjawaban iman, dan memerankan peran sebagai kepala keluarga adalah sebuah misi pertanggungjawaban kehidupan dan respon yang benar atas mandat budaya dari Allah.

Menjadi kepala keluarga juga merupakan hal yang sangat bernilai dan kehormatan, karena tidak ada pria yang menjadi kepala keluarga secara kebetulan. Untuk menjadi kepala keluarga yang efektif harus memiliki visi obsesi agung yang terencana, fokus dan mempunyai tujuan seturut kebenaran Alkitab. Banyak sekali tantangan yang harus dihadapi sebagai kepala keluarga untuk dapat melalui dan menunaikan peran ini dengan baik tentunya para suami, para ayah harus terus hidup sesuai dengan kehendak Allah, yang telah memanggil para suami, para ayah ke dalam Kerajaan dan kemuliaan-Nya, karena tidak ada yang lebih bermakna dalam hidup, selain hidup dalam sikap takut, dan hormat serta berkenan

${ }^{61}$ Wright and Oliver, Raising Kids To Love Jesus. 
bagi Allah selama masih diberi kesempatan menumpang di bumi ini bersama keluarga yang dicintai.

\section{Daftar Pustaka}

Arifianto, Yonatan Alex. "Pentingnya Pendidikan Kristen Dalam Membangun Kerohanian Keluarga Di Masa Pandemi Covid-19.” REGULA FIDEI: Jurnal Pendidikan Agama Kristen 5, no. 2 (2020): 94-106.

Arifianto, Yonatan Alex, and Joseph Christ Santo. "Iman Kristen Dan Perundungan Di Era Disrupsi." Angelion: Jurnal Teologi dan Pendidikan Kristen 1, no. 2 (2020): 149-163. Chapman, Gary. Five Signs of a Functional Family. 1st ed. Batam: Interaksara, 2000.

Daugherty, Billy Joe. Pernikahan Yang Kokoh. 4th ed. Jakarta: Metanoia, 2006.

Dobson, James. Mendidik Putra Anda. 2nd ed. Jakarta: Immanuel, 2006.

Dobson, James, and Shirley Dobson. Night Light For Parents. 1st ed. Tangerang: Gospel Press, 2007.

Don, and Sally Meredith. Keduanya... Menjadi Satu. 1st ed. Batam: Gospel Press, 2006.

Evimalinda, Rita, Eko Prasetyo, and P A K Sihombing3 Prodi. "Urgensi Pemuridan Keluarga Sebagai Gereja Mini Dalam Akselerasi Amanat Agung Di Tengah Pandemi Covid-19" (n.d.).

Family, Focus On The. Menjadi Suami Yang Andal. 1st ed. Yogyakarta: Andi Offset, 2009. Gule, Yosefo. "Peranan Kepala Keluarga Sebagai Imam Di Tengah-Tengah Keluarga Dimasa Pandemi Covid-19." Voice of Wesley: Jurnal Ilmiah Musik dan Agama 4, no. 1 (2020): 54-66.

Ingram, Chip. Effective Parenting In A Defective World. 1st ed. Tangerang: WorldTeach Indonesia, 2006.

JR., Voddie Baucham. Family Shepherds Gembala-Gembala Keluarga. 1st ed. Bandung: Pionir Jaya, 2012.

Lawson, Steven J. Warisan Abadi. 2nd ed. Jakarta: Metanoia, 2005.

McDowell, Josh. The Father Connection. 1st ed. Jakarta: Metanoia, 2004.

Moore, Russell. Keluarga Di Tengah Badai Dunia. 1st ed. Jakarta: OMID Publishing House, 2020

Morley, Patrick, and David Delk. The Dad in the Mirror. 1st ed. Yogyakarta: Andi Offset, 2004.

Morley, Patrick M. The Man In The Mirror. 1st ed. Yogyakarta: Katalis, 2020.

Munroe, Myles, and David Burrows. Kingdom Parenting. 1st ed. Jakarta: Immanuel, 2009.

Parsons, Rob. 60 Menit Ayah - Satu Jam Untuk Mengubah Kehidupan Anak Anda. 2nd ed. Jakarta: Immanuel, 2002.

Paul, and Billie Kaye Tsika. Get Married, Stay Married. 1st ed. Jakarta: Immanuel, 2012.

Putri, Dyah Purbasari Kusumaning, and Sri Lestari. "Pembagian Peran Dalam Rumah Tangga Pada Pasangan Suami Istri Jawa.” Jurnal Penelitian Humaniora 16, no. 1 (2016): 72-85.

Sibarani, Yosua, and Yonatan Alex Arifianto. "Studi Analisis Makna Kata 'Berahi' Dan 'Berkuasa' Dalam Kejadian 3:16 Dan Implikasinya Bagi Rumah Tangga Kristen Masa 
Kini.” Sola Scriptura: Jurnal Teologi 1, no. 2 (2020): 118-134.

Simorangkir, Sri Lina Betty Lamsihar, and Yonatan Alex Arifianto. "Makna Hidup Adalah Kristus Berdasarkan Filipi 1: 21 Dan Implikasinya Bagi Orang Percaya." CARAKA: Jurnal Teologi Biblika dan Praktika 1, no. 2 (2020): 228-242.

Slayton, Gregory W. Be A Better Dad Today 10 Panduan Menjadi Ayah Hebat. 1st ed. Jakarta: Persekutuan Gereja-Gereja Tionghoa Indonesia, 2015.

Stephen, and Alex Kendrick. The Resolution For Men. 1st ed. Bandung: Pionir Jaya, 2014. Talizaro Tafonao. "Peran Pendidikan Agama Kristen Dalam Keluarga Terhadap Perilaku Anak." Edudikara: Jurnal Pendidikan dan Pembelajaran 3, no. 2 (2018).

Thomas, Gary. Devotions for Sacred Parenting. 1st ed. Yogyakarta: Yayasan Gloria Katalis, 2013.

Thompson, Marjorie L. Keluarga Sebagai Pusat Pembentukan. 5th ed. Jakarta: BPK Gunung Mulia, 2012.

Tripp, Tedd. Shepherding A Child's Heart. 1st ed. Malang: Gandum Mas, 2002.

Weidmann, Josh, and Jim Weidmann. Ayah Aku Ingin Bicara. 1st ed. Yogyakarta: Gloria Graffa, 2006.

Wright, H. Norman, and Gary J. Oliver. Raising Kids To Love Jesus. 3rd ed. Yogyakarta: Gloria Graffa, 2013.

Young, Ed. The 10 Commandments Of Parenting. 1st ed. Bandung: Lembaga Literatur Baptis, 2005.

Zaluchu, Sonny Eli. "Struktur Artikel Untuk Jurnal Ilmiah Dan Teknik Penulisannya.” In Strategi Menulis Jurnal Untuk Ilmu Teologi, edited by Sonny Eli Zaluchu, 1-21. 1st ed. Semarang: Golden Gate Publishing Semarang, 2020. 